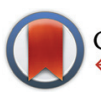

CrossMark \& click for updates

Cite this: Dalton Trans., 2016, 45 7748

Received 1st March 2016, Accepted 31st March 2016 DOI: $10.1039 / c 6 d t 00830 e$ www.rsc.org/dalton

\title{
Luminescent osmium(॥) bi-1,2,3-triazol-4-yl complexes: photophysical characterisation and application in light-emitting electrochemical cells $\uparrow$
}

\author{
Daniel A. W. Ross, ${ }^{a}$ Paul A. Scattergood, ${ }^{a}$ Azin Babaei, ${ }^{b}$ Antonio Pertegás, ${ }^{b}$ \\ Henk J. Bolink ${ }^{\star b}$ and Paul I. P. Elliott*a
}

\begin{abstract}
The series of osmium(॥) complexes $\left[\mathrm{O}(\mathrm{bpy})_{3-n}(\mathrm{btz})_{n}\right]\left[\mathrm{PF}_{6}\right]_{2}$ (bpy $=2,2^{\prime}$ - bipyridyl, btz $=1,1^{\prime}$-dibenzyl-4,4'bi-1,2,3-triazolyl, $1 n=0,2 n=1,3 n=2,4 n=3$ ), have been prepared and characterised. The progressive replacement of bpy by btz leads to blue-shifted UV-visible electronic absorption spectra, indicative of btz perturbation of the successively destabilised bpy-centred LUMO. For $\mathbf{4}$, a dramatic blue-shift relative to the absorption profile for $\mathbf{3}$ is observed, indicative of the much higher energy LUMO of the btz ligand over that of bpy, mirroring previously reported data on analogous ruthenium(II) complexes. Unlike the previously reported ruthenium systems, heteroleptic complexes $\mathbf{2}$ and $\mathbf{3}$ display intense emission in the far-red/near-infrared ( $\lambda_{\max }=724$ and $713 \mathrm{~nm}$ respectively in aerated acetonitrile at RT) as a consequence of higher lying, and hence less thermally accessible, ${ }^{3} \mathrm{MC}$ states. This assertion is supported by ground state DFT calculations which show that the d $\sigma^{*}$ orbitals of 1 to 4 are destabilised by between 0.60 and $0.79 \mathrm{eV}$ relative to their $\mathrm{Ru}(\mathrm{II})$ analogues. The homoleptic complex $\mathbf{4}$ appears to display extremely weak room temperature emission, but on cooling to $77 \mathrm{~K}$ the complex exhibits highly intense blue emission with $\lambda_{\max } 444 \mathrm{~nm}$. As complexes 1 to 3 display room temperature luminescent emission and readily reversible Os(II)/(III) redox couples, light-emitting electrochemical cell (LEC) devices were fabricated. All LECs display electroluminescent emission in the deep-red/near-IR ( $\lambda_{\max }=695$ to $730 \mathrm{~nm}$ ). Whilst devices based on $\mathbf{2}$ and $\mathbf{3}$ show inferior current density and luminance than LECs based on $\mathbf{1}$, the device utilising $\mathbf{3}$ shows the highest external quantum efficiency at $0.3 \%$.
\end{abstract}

\section{Introduction}

The photophysics of $\mathrm{d}^{6}$ oligopyridine based complexes have been extensively investigated over the past four decades. ${ }^{1,2}$ This interest stems from the potential application of these complexes from light-harvesting and solar energy conversion $^{3-5}$ to artificial lighting. ${ }^{6-8}$ The control and optimisation of the excited state energies of these complexes in relation to their use within the aforementioned applications has therefore been a focus of innumerable studies on ligand design for these systems.

Complexes of Os(II) in particular have been of significant interest since the 1980s, with the photophysical properties of the parent complex of the family, Os(bpy $)_{3}{ }^{2+}$, having been

\footnotetext{
${ }^{a}$ Department of Chemistry, University of Huddersfield, Queensgate, Huddersfield, HD1 3DH, UK. E-mail: p.i.elliott@hud.ac.uk

${ }^{b}$ Instituto de Ciencia Molecular (ICMol), Universidad de Valencia, C/ Catedrático José Beltrán, 2, 46980 Paterna, Spain. E-mail: henk.bolink@uv.es

$\dagger$ Electronic supplementary information (ESI) available. See DOI: 10.1039/ c6dt00830e
}

described in detail and compared and contrasted to its wellknown $\mathrm{Ru}(\mathrm{II})$ analogue. ${ }^{9-12}$ Subsequent work has predominantly centred around modification of the ligand set, for example, introducing other simple diimines such as 1,10-phenanthroline, ${ }^{9,13}$ terpyridines ${ }^{14-16}$ or dipyridophenazine $(\mathrm{dppz})^{17,18}$ and also expanding the ligand architecture to permit coordination to more than one metal centre, thus giving access to a variety of novel homo- and heterometallic dimers $^{14,19}$ and dendrimers. ${ }^{20,21}$ The appeal of using Os(II) lies primarily in the inherent ground and excited state stability of its polypyridyl complexes, reversible redox chemistry and broadly panchromatic optical absorption properties. ${ }^{20}$ This latter property is partially a consequence of the high spinorbit coupling constant for Os permitting the occurrence of both spin-allowed ${ }^{1} \mathrm{MLCT}$ and spin-forbidden direct ${ }^{3} \mathrm{MLCT}$ electronic transitions. ${ }^{22}$ Furthermore, the ${ }^{3}$ MLCT states are frequently relatively long-lived ${ }^{23}$ and often undergo radiative deactivation through phosphorescent emission. Consequently, Os(II) complexes have been employed in applications ranging from emissive intercalating DNA probes ${ }^{17}$ to semi-conductor sensitisers $^{24,25}$ and light-absorbing molecular antennae. ${ }^{21,26}$ 
Ligand systems based on the use of 1,2,3-triazoles as a replacement for pyridine donors have recently generated significant interest, where facile synthesis through so-called 'click' chemistry opens up many possibilities for readily tuneable photophysical properties. ${ }^{27-30}$ Several examples of $\operatorname{Ir}(\mathrm{III})$ complexes featuring 1,2,3-triazoles have been reported as colour tuneable emitters ${ }^{31-34}$ and further incorporated within light emitting devices. ${ }^{35-38}$

We and others have recently investigated 4,4'-bi-1,2,3-triazolyl (btz) ligands. For example, complexes of the form $\left[\operatorname{Ir}(\text { apy })_{2}(\text { btz })\right]^{+}$, where apy is a 2-arylpyridine, were shown to be luminescent. ${ }^{33,39}$ Our group has also investigated the photophysics and photochemistry of ruthenium(II) btz complexes. ${ }^{40-43}$ Fletcher $^{44}$ and Monkowius ${ }^{45}$ had previously shown homoleptic complexes of the type $\left[\mathrm{Ru}(\mathrm{btz})_{3}\right]^{2+}$ to be non-emissive. We proceeded to prepare and characterise the series of complexes $\left[\mathrm{Ru}(\mathrm{bpy})_{3-n}(\mathrm{btz})_{n}\right]^{2+}(n=1-3) .{ }^{40}$ Increasing btz content results in a blue-shift in the ${ }^{1}$ MLCT band with a very pronounced shift on going from $n=2$ to $n=3$. Density functional theory (DFT) calculations indicate that the LUMO of the btz ligand is approximately $1 \mathrm{eV}$ higher than that of bpy, thus explaining the large shift in the MLCT band on replacement of the final bpy ligand. Time-dependent DFT data revealed that for the bpy-containing complexes in the series that the lowest triplet excited state was ${ }^{3}$ MLCT in nature. However, for $\left[\mathrm{Ru}(\mathrm{btz})_{3}\right]^{2+}$ the $\mathrm{S}_{1}$ and $\mathrm{T}_{1}$ states were shown to have ${ }^{3} \mathrm{MC}$ character. The narrowing of the ${ }^{3} \mathrm{MLCT}-{ }^{3} \mathrm{MC}$ gap in the heteroleptic complexes $\left[\mathrm{Ru}(\mathrm{bpy})_{2}(\mathrm{btz})\right]^{2+}$ and $[\mathrm{Ru}(\mathrm{bpy})$ $\left.(\mathrm{btz})_{2}\right]^{2+}$ also results in photochemical btz ligand ejection reactivity, which in the case of the latter complex proceeds with the observation of a highly stable ligand loss intermediate. ${ }^{41}$

Triazole-containing ligands therefore allow access to efficient phosphorescent complexes on the one hand but also to complexes displaying unique photochemical reactivity on the other. Further, whilst there are now numerous reports on the coordination chemistry and photophysical properties of 1,2,3-triazole complexes of ruthenium and other $\mathrm{d}^{6}$ metals, there is to our knowledge only one report of triazole coordination to osmium. ${ }^{46}$ The aforementioned dichotomous nature exhibited by triazole-containing complexes inspired us to investigate the osmium analogues of the previously studied ruthenium btz family of complexes and explore their electroluminescence properties when used in light-emitting electrochemical cells (LECs). Since their discovery in 1996 by Pei, ${ }^{47}$ LECs have been investigated as potential inexpensive lighting devices due to their simplicity. In LECs, different materials such as conjugated polymers blended with ionic liquids, ionic dyes or organometallic complexes have been used as emitters. Nevertheless, due to the intrinsically higher photoluminescence efficiency of phosphorescent compounds, the most efficient LECs have been obtained using ionic transition metal complexes (iTMCs) as emitters. ${ }^{4-52}$ Commonly employed metal centres used in iTMC for LECs are Ir(III) and $\mathrm{Ru}(\mathrm{II})$, due to their high stability and efficient photoluminescence, whereas other transition metal complexes have been studied only on a very limited basis. Among these, Os(II) has been used in the preparation of phosphorescent emitters for $\mathrm{LECs}^{53-55}$ and for more common organic light-emitting diodes (OLEDs). ${ }^{56}$ However, the application of Os(II) iTMCs in LECs has not yet been developed to its full potential.

We report here the synthesis and characterisation of the series of complexes $\left[\mathrm{Os}(\mathrm{bpy})_{3-n}(\mathrm{btz})_{n}\right]^{2+}(1 n=0 ; 2 n=1 ; 3 n=$ $2 ; 4 n=3)$. We will show that in contrast to their ruthenium analogues that $\mathbf{1}$ to $\mathbf{3}$ are emissive at room temperature in the deep-red/near-infrared region of the spectrum. Further, these complexes have been used as phosphors in deep-red/nearinfrared light-emitting electrochemical cells.

\section{Results \& discussion}

The heteroleptic complex $\left[\mathrm{Os}(\mathrm{bpy})_{2}(\mathrm{btz})\right]^{2+}(2)$ was conveniently prepared from $\left[\mathrm{Os}(\mathrm{bpy})_{2} \mathrm{Cl}_{2}\right]$ by reaction with one equivalent of btz and was isolated as its hexafluorophosphate salt (Scheme 1). The ${ }^{1} \mathrm{H}$ NMR spectrum of 2 (Fig. S10 $\dagger$ ) exhibits a set of eight resonances for the bpy ligands, indicative of the $C_{2}$ symmetry of the complex. These are accompanied by a singlet resonance for the btz triazole ring protons at $\delta 8.34$ and a pair of roofed doublets at $\delta 5.45$ and $5.49\left(J_{\mathrm{HH}}=15 \mathrm{~Hz}\right)$ corresponding to the diastereotopic methylene protons of the btz benzyl substituents.

The synthesis of the second heteroleptic complex [Os(bpy) $\left.(\mathrm{btz})_{2}\right]^{2+}(3)$ was initially attempted via a similar route to that of 2. $\left[\mathrm{NH}_{4}\right]_{2}\left[\mathrm{OsCl}_{6}\right]$ was reacted with two equivalents of btz to yield $\left[\mathrm{Os}(\mathrm{btz})_{2} \mathrm{Cl}_{2}\right]$, with ${ }^{1} \mathrm{H}$ NMR analysis revealing two inequivalent triazole rings within the ligand, indicating the
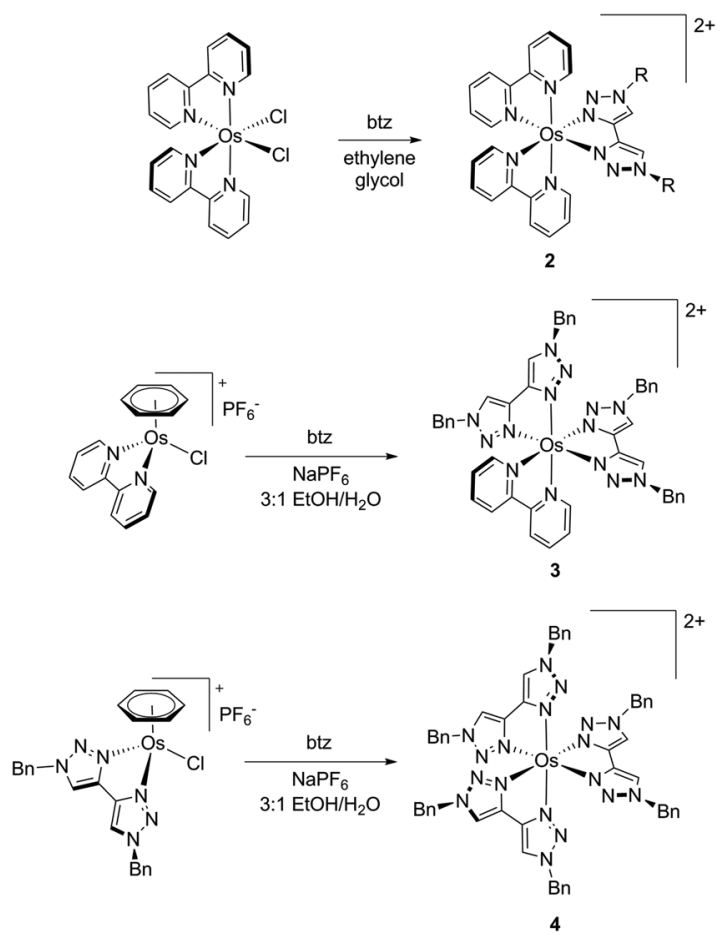

Scheme 1 Synthesis of complexes 2 to 4 . 
successful isolation of the $C_{2}$ symmetric intermediate. However, subsequent reaction with one equivalent of bpy proved unsuccessful, furnishing only a yellow/green compound, the ${ }^{1} \mathrm{H}$ NMR spectrum of which contained only one set of btz resonances and no signals corresponding to bpy. The resemblance of this spectrum to that of $\left[\mathrm{Os}(\mathrm{btz})_{3}\right]^{2+}$ (vide infra) and the obvious differences to that of the intermediate [Os $(\mathrm{btz})_{2} \mathrm{Cl}_{2}$ ], allow us to speculate that ligand exchange may have occurred under these reaction conditions to give only a homoleptic product. Consequently, 3 was prepared via an alternative procedure making use of a bipyridine-containing intermediate (Scheme 1), a strategy which has been employed in our previous work concerning the synthesis of the $\mathrm{Ru}$ analogue of 3. ${ }^{40,41}$ Thus, refluxing $\left[\mathrm{Os}\left(\eta^{6}-\mathrm{C}_{6} \mathrm{H}_{6}\right)(\mathrm{bpy})(\mathrm{Cl})\right]\left[\mathrm{PF}_{6}\right]$ in ethanol/ water with two equivalents of btz yields 3 , which was isolated as a dark green powder as its hexafluorophosphate salt. The ${ }^{1} \mathrm{H}$ NMR spectrum of 3 (Fig. S12 $\dagger$ ) exhibits a total of four resonances for the bpy ligand along with two sets of signals for the inequivalent triazole rings $(\delta 8.30,8.33)$ and benzylic methylene environments $(\delta 5.47,5.53)$ of the btz ligands, again consistent with a complex possessing $C_{2}$ symmetry.

Whilst single crystals were successfully grown for complexes 2 and 3 , these repeatedly proved to be unsuitable for the collection of satisfactory X-Ray diffraction data.

The homoleptic complex $\mathbf{4}$ may be readily prepared directly from $\left[\mathrm{NH}_{4}\right]_{2}\left[\mathrm{OsCl}_{6}\right]$ by heating to reflux in ethylene glycol in the presence of three equivalents of btz for 2 hours. However, it was found that this method repeatedly lead to the formation of small quantities of an additional Os complex, characterised by the presence of four broad resonances in the ${ }^{1} \mathrm{H}$ NMR spectrum at $\delta 3.47,6.32,6.57$ and 11.44 , and by mass spectrometry as a mono-osmiated species with $m / z=894.18$. As we were unable to either identify or separate this species, 4 was alternatively prepared in an analogous manner to that of 3. Briefly, $\left[\mathrm{Os}\left(\eta^{6}-\mathrm{C}_{6} \mathrm{H}_{6}\right)(\mathrm{btz})(\mathrm{Cl})\right]\left[\mathrm{PF}_{6}\right]$ was heated to reflux in ethanol/ water with two further equivalents of btz, which in the presence of $\mathrm{NaPF}_{6}$ affords exclusively 4 as the hexafluorophosphate salt. The ${ }^{1} \mathrm{H}$ NMR spectrum of 4 (Fig. S14 $\dagger$ ) is very simple, containing a singlet for the six triazole ring protons at $\delta 8.33$ and a signal for the methylene protons of the btz benzyl substituents at $\delta 5.50$. The remaining protons of the phenyl rings fall within a multiplet at $\delta 7.29-7.38$, with the ortho protons being discernable as a separate resonance centred at $\delta$ 7.14. Despite numerous attempts, single crystals of $\mathbf{4}$ could not be successfully grown.

Cyclic voltammograms were recorded for complexes 1 to 4 and are presented in Fig. 1 with electrochemical data summarised in Table 1. All complexes show a reversible Os(II)/Os(III) oxidation process between +0.46 and $+0.53 \mathrm{~V} v s . \mathrm{Fc}^{+} / \mathrm{Fc}$ which undergoes a slight cathodic shift with increasing btz content within the ligand set. This shift to lower potential occurs as bpy is sequentially replaced by btz due to the weaker electron withdrawing ability of the latter and the resulting increase in electron density at the metal centre. The HOMO in 1 to 4 is therefore determined to be localised on the Os centre. For complex 2, a reversible bpy-centred reduction is observed at

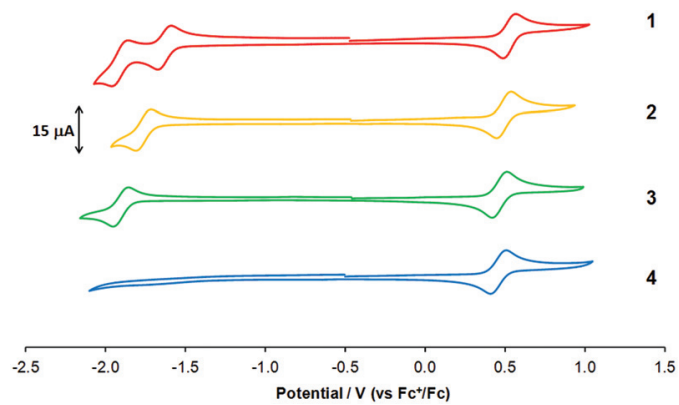

Fig. 1 Cyclic voltammetry traces for $1.8 \mathrm{mmol} \mathrm{dm}{ }^{-3} \mathrm{CH}_{2} \mathrm{Cl}_{2}$ solutions of complexes 1-4, recorded at r.t. at $100 \mathrm{mV} \mathrm{s}^{-1}$. Solutions contained $0.2 \mathrm{~mol} \mathrm{dm}^{-3} \mathrm{NBu}_{4} \mathrm{PF}_{6}$ as supporting electrolyte. All potentials are shown against the $\mathrm{Fc}^{+} / \mathrm{Fc}$ couple.

Table 1 Summarised electrochemical data for $1.8 \mathrm{mmol} \mathrm{dm}{ }^{-3} \mathrm{CH}_{2} \mathrm{Cl}_{2}$ solutions of complexes 1-4, measured at r.t. at $100 \mathrm{mV} \mathrm{s}^{-1}$. Potentials are shown in $\mathrm{V} v \mathrm{vs}$. $\mathrm{Fc}^{+} / \mathrm{Fc}$. Anodic-cathodic peak separations, $\Delta E_{\mathrm{a}, \mathrm{c}}$, are shown in $\mathrm{mV}$ within brackets where applicable. ( $\Delta E_{\mathrm{a}, \mathrm{c}}$ for $\mathrm{Fc}^{+} / \mathrm{Fc}$ was typically $80 \mathrm{mV}$ )

\begin{tabular}{lll}
\hline Complex & Oxidation/V & Reduction/V \\
\hline $\mathbf{1}$ & $+0.53(83)$ & $-1.63(86),-1.91(95)$ \\
$\mathbf{2}$ & $+0.49(90)$ & $-1.76(93)$ \\
$\mathbf{3}$ & $+0.47(95)$ & $-1.90(95)$ \\
$\mathbf{4}$ & $+0.46(98)$ & - \\
\hline
\end{tabular}

$-1.76 \mathrm{~V}$ which is cathodically shifted by $0.13 \mathrm{~V}$ relative to the first reduction potential of $\mathbf{1}$, indicating destabilisation of the LUMO of the complex in agreement with the blue-shifted MLCT absorption maxima (vide infra). For 3 , a reversible bpycentred reduction is again observed centred at $-1.90 \mathrm{~V}$, cathodically shifted by a further $0.14 \mathrm{~V}$ relative to that of 2 . For the homoleptic complex 4 no reduction potential is observed within the available electrochemical solvent window, indicative of the much higher energy LUMO of btz over that of bpy.

UV-visible electronic absorption spectra were recorded for all complexes in acetonitrile solutions (Fig. 2 and Table 2). The bpy-containing complexes $\mathbf{1}$ to $\mathbf{3}$ all show an intense bpycentred $\pi \rightarrow \pi^{*}$ based band centred around $290 \mathrm{~nm}$ which is

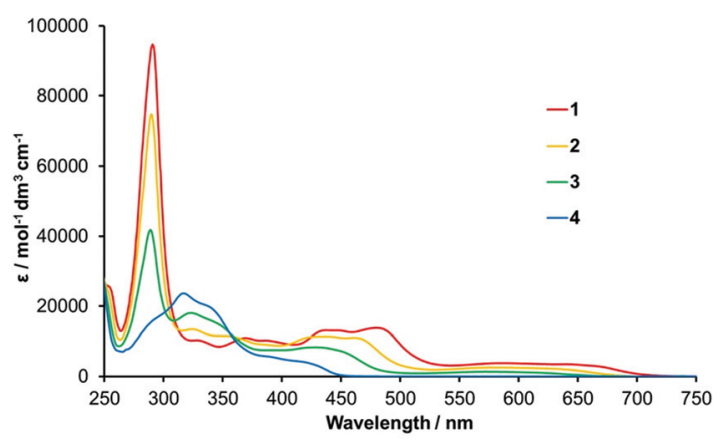

Fig. 2 UV-visible electronic absorption spectra for acetonitrile solutions of complexes 1-4. 
Table 2 Summarised photophysical data for 1 to 4

\begin{tabular}{|c|c|c|c|c|c|}
\hline Complex & $\lambda(\mathrm{abs})^{a} / \mathrm{nm}$ & & $\lambda(\mathrm{em}) / \mathrm{nm}$ & $\tau / \mathrm{ns}$ & $\Phi_{\mathrm{em}}^{e} / \%$ \\
\hline \multirow[t]{2}{*}{1} & $\begin{array}{l}651,585,480,449 \\
435,368,328,291\end{array}$ & $\mathrm{RT}^{a}$ & $732^{c}$ & $38^{a}$ & $0.5^{a}$ \\
\hline & & $77 \mathrm{~K}^{b}$ & $706,778^{c}$ & $58^{f}$ & $0.8^{f}$ \\
\hline \multirow[t]{2}{*}{2} & $\begin{array}{l}634,576,463,440 \\
427,356,325,289\end{array}$ & $\mathrm{RT}^{a}$ & $724^{c}$ & $49^{a}$ & $0.5^{a}$ \\
\hline & & $77 \mathrm{~K}^{b}$ & $698,767^{c}$ & $83^{f}$ & $0.9^{f}$ \\
\hline \multirow[t]{2}{*}{3} & $\begin{array}{l}613,571,450,429 \\
341,323,288\end{array}$ & $\mathrm{RT}^{a}$ & $713^{c}$ & $66^{a}$ & $0.6^{a}$ \\
\hline & & $77 \mathrm{~K}^{b}$ & $673,730^{c}$ & $124^{f}$ & $1.4^{f}$ \\
\hline \multirow[t]{2}{*}{4} & $\begin{array}{l}422,391,340,320, \\
296\end{array}$ & $\mathrm{RT}^{a}$ & - & - & - \\
\hline & & $77 \mathrm{~K}^{b}$ & $444,474,495^{d}$ & & \\
\hline
\end{tabular}

${ }^{a}$ In aerated MeCN. ${ }^{b}$ In $4: 1 \mathrm{EtOH} / \mathrm{MeOH}$ glass. ${ }^{c} \lambda_{\mathrm{ex}}=600 \mathrm{~nm} .{ }^{d} \lambda_{\mathrm{ex}}=$ $400 \mathrm{~nm} .{ }^{e}$ Relative to $\left[\mathrm{Ru}(\mathrm{bpy})_{3}\right]\left[\mathrm{PF}_{6}\right]_{2} \Phi_{\mathrm{em}}=0.018$ in aerated MeCN. ${ }^{58}$ ${ }^{f}$ Deaerated MeCN (photophysical data for $\mathrm{CH}_{2} \mathrm{Cl}_{2}$ solutions is presented within the ESI).

seen to decrease in intensity as bpy ligands are sequentially replaced by btz. 1 displays further electronic transitions in the visible region, with those around $450 \mathrm{~nm}$ assigned as being ${ }^{1}$ MLCT in character, with bands of weaker intensity at wavelengths above $550 \mathrm{~nm}$ due to direct population of ${ }^{3} \mathrm{MLCT}$ states as a consequence of the high spin-orbit coupling constant of Os. ${ }^{22,57}$ The visible region of the spectrum of 2 has a similar panchromatic absorption profile to that of $\mathbf{1}$, tailing off at $700 \mathrm{~nm}$ in which the MLCT bands are blue-shifted as the LUMO is destabilised on replacement of a bpy ligand by btz. Likewise, the ${ }^{1,3}$ MLCT bands observed for 3 are further blue shifted, with $\lambda_{\max }$ at 429 and $450 \mathrm{~nm}$ for the ${ }^{1}$ MLCT band and the ${ }^{3}$ MLCT band seen to tail off around $650 \mathrm{~nm}$. Spectra for 2 and 3 also show increased absorption in the region 320 to $350 \mathrm{~nm}$ which is assigned to btz-localised ${ }^{1}$ MLCT transitions.

The absorption spectrum of $\mathbf{4}$ is heavily blue-shifted compared to the other complexes, with ${ }^{1,3}$ MLCT based bands tailing off at $450 \mathrm{~nm}$. A more intense band observed in the near-UV region with an absorption maximum at $320 \mathrm{~nm}$ is tentatively assigned as arising from overlapping ${ }^{1} \mathrm{MLCT} /{ }^{1} \mathrm{LC}$ transitions. This mirrors the behaviour exhibited by the corresponding ruthenium analogue $\left[\mathrm{Ru}(\mathrm{btz})_{3}\right]^{2+}$ which has almost no absorption in the visible region of the spectrum. ${ }^{40}$

Complexes 1 to 3 are observed to be emissive at room temperature in aerated solutions of MeCN (Fig. 3 (top) and 4). The broad, featureless bands in the deep-red/near-infrared region are attributed to emissive states which are predominantly ${ }^{3} \mathrm{MLCT}$ in character. In comparison, $\left[\mathrm{Ru}(\mathrm{bpy})_{2}(\mathrm{btz})\right]^{2+}$ exhibits highly quenched emission compared to $\left[\mathrm{Ru}(\mathrm{bpy})_{3}\right]^{2+}$, whilst no room temperature emission is observed for $\left[\mathrm{Ru}(\mathrm{bpy})(\mathrm{btz})_{2}\right]^{2+}$ and $\left[\mathrm{Ru}(\mathrm{btz})_{3}\right]^{2+} \cdot{ }^{40}$ The enhancement in emission here is likely
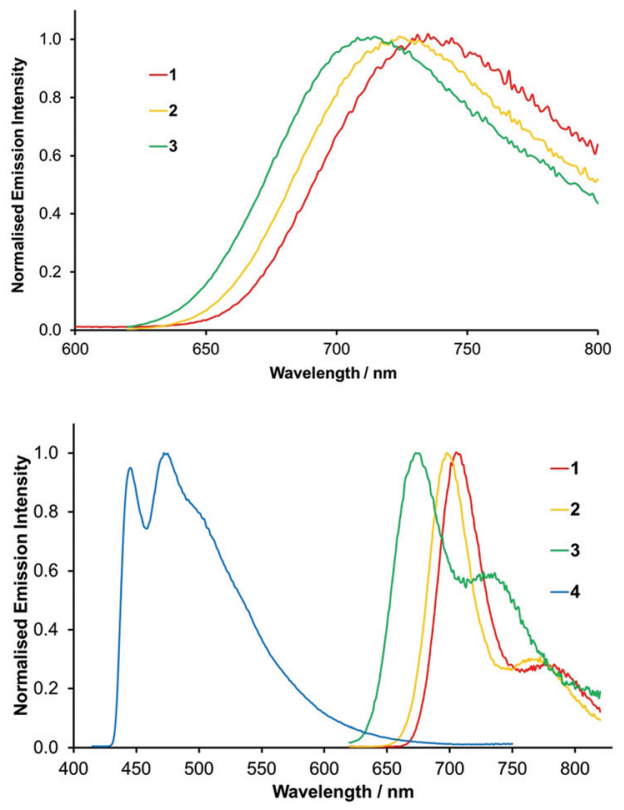

Fig. 3 Top: Normalised emission spectra recorded for aerated MeCN solutions of $1-3$ at r.t. Bottom: Low temperature emission spectra $(77 \mathrm{~K})$ recorded for $1-4$ in a $4: 1 \mathrm{EtOH}: \mathrm{MeOH}$ glass. $\left(1-3: \lambda_{\mathrm{ex}}=600 \mathrm{~nm} ; 4\right.$ : $\lambda_{\mathrm{ex}}=400 \mathrm{~nm}$ ).

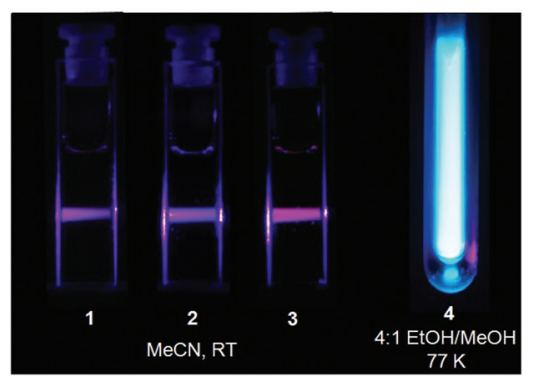

Fig. 4 Photograph composite of luminescent emission from complexes 1 to 4 .

to be a consequence of higher energy ${ }^{3} \mathrm{MC}$ states in $\mathbf{1}$ to 3 relative to their ruthenium(II) analogues due to the greater ligand field splitting and higher energy $\mathrm{d} \sigma^{*}$ orbitals of the $5 \mathrm{~d}$ metal centre (vide infra).

Complex 2 exhibits a broad emission band $\left(\lambda_{\max } 724 \mathrm{~nm}\right)$ that is blue-shifted by $8 \mathrm{~nm}$ relative to that of 1 , with that of 3 further shifted to higher energy with $\lambda_{\max }$ at $713 \mathrm{~nm}$. This shift to higher emission energy as bpy is sequentially replaced by btz is indicative of a destabilisation of the LUMO and a corresponding increase in the HOMO-LUMO energy gap across the series. This trend is in excellent agreement with the increase in HOMO-LUMO separation across 1-3 as measured by cyclic voltammetry and electronic absorption spectroscopy. (vide supra). Emission spectra were also recorded for 1-3 in dichloromethane (ESI $\dagger$ ), with $\lambda_{\max }$ (717-697 $\mathrm{nm}$ ) displaying a small solvatochromic shift to higher energy consistent with a decrease in the polarity of the solvent. 
Contrary to initial expectations based on the non-emissive properties of the analogous complex $\left[\mathrm{Ru}(\mathrm{btz})_{3}\right]^{2+}, \mathbf{4}$ appears to be extremely weakly emissive in acetonitrile at room temperature with a band discernible above the noise at approximately $460 \mathrm{~nm}$ after removal of solvent Raman scattering signals (see ESI†). The complex is, however, intensely emissive in a $4: 1$ EtOH/MeOH glass at $77 \mathrm{~K}$ (Fig. 3 (bottom) \& 4) and exhibits a structured band with maxima at 444, 474 and $495 \mathrm{~nm}$. The low temperature emission profiles of $\mathbf{1}$ to $\mathbf{3}$ were also obtained in rigid $\mathrm{EtOH} / \mathrm{MeOH}$ glasses at $77 \mathrm{~K}$ (Fig. 3, bottom). In each case the complexes exhibit structured emission bands where the emission maxima display the expected rigidochromic blueshift relative to their solution state spectra with $\lambda_{\max }$ lying between 673 and $706 \mathrm{~nm}$. The trend in emission energy for 1-3 remains the same, being progressively shifted to higher energy with increasing btz content in the ligand set.

Luminescence lifetimes for the emission observed for 1-3 in aerated $\mathrm{MeCN}$ at room temperature were measured and are displayed in Table 2. These values are seen to increase across the series upon successive replacement of bpy ligands with btz from 38 to $66 \mathrm{~ns}$, and also upon changing the polarity of the solvent with lifetimes from 73 to $123 \mathrm{~ns}$ being measured for 1-3 in aerated dichloromethane (ESI $\dagger$ ). The increase in lifetime is a consequence of the gradual increase in HOMO-LUMO energy gap and corresponding destabilisation of the emissive ${ }^{3} \mathrm{MLCT}$ state, as expected in accordance with the energy gap law. ${ }^{9,10}$

In order to complement our experimental studies we carried out computational DFT calculations on complexes 1 to 4. In the case of the btz-containing complexes the benzyl substituents were simplified to methyl groups. Plots of selected molecular orbitals and a comparative molecular orbital energy level diagram are provided in Fig. 5. In each case the HOMOs for the optimised ground state geometries of 1 to 4 are $O \mathrm{Os}_{\mathrm{z}^{2}}$ in character, which are destabilised by 0.27 to $0.35 \mathrm{eV}$ compared to the corresponding $4 \mathrm{~d}_{\mathrm{z}^{2}}$ orbitals of their ruthenium analogues. Due to the higher energy osmium-based HOMOs in 1 to 4 the HOMO-LUMO gap is reduced compared to the corresponding ruthenium series (3.11-4.27 eV versus 3.46$4.69 \mathrm{eV}$ respectively) accounting for the significant red-shift that is observed in the optical absorption spectra.

For the bpy-containing complexes $\mathbf{1}$ to $\mathbf{3}$ the LUMO is localised on the bpy ligands, having $\pi^{*}$ character in the same manner as their ruthenium analogues. For the homoleptic complex 4 the LUMO is distributed equally over the three btz ligands. Progressing across the series both the HOMO and LUMO are destabilised (Table 3), more so for the latter resulting in an increased HOMO-LUMO energy gap in agreement with the experimental spectroscopic and electrochemical data; from complex 1 to 3 the HOMO-LUMO gap increases by $0.29 \mathrm{eV}$ as bpy ligands are replaced by btz. Similarly to the analogous ruthenium series the HOMO-LUMO separation increases markedly by $0.87 \mathrm{eV}$ upon going from 3 to 4 with the final replacement of bpy by btz necessitating the change from a bpy- to btz-localised LUMO.

The greater room temperature emission exhibited by 1 to 4 compared to the previously reported ruthenium series is pro-
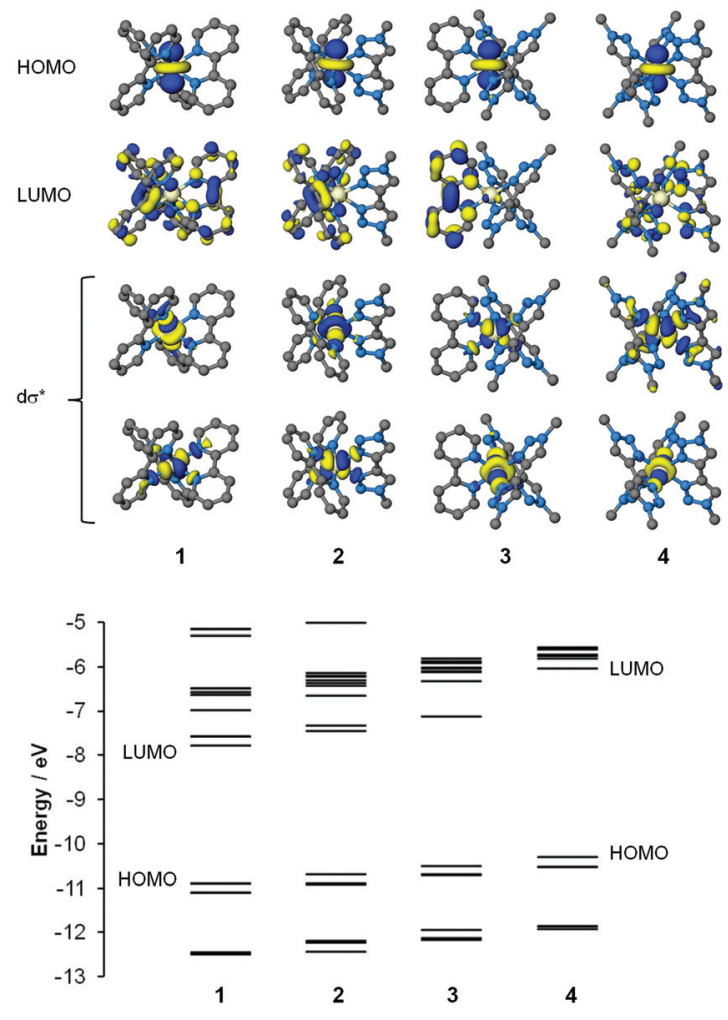

Fig. 5 Plots of the HOMO, LUMO and d $\sigma^{*}$ orbitals for 1 to 4 (top) and comparative molecular orbital energy level diagram for 1 to 4 (bottom).

Table 3 Calculated energies (eV) of the HOMO, LUMO and $d \sigma^{*}$ orbitals of complexes 1 to 4

\begin{tabular}{lllll}
\hline & 1 & 2 & 3 & 4 \\
\hline HOMO & -10.88 & -10.69 & -10.51 & -10.29 \\
LUMO & -7.77 & -7.44 & -7.11 & -6.03 \\
$\mathrm{~d} \sigma^{*}$ & -4.71 & -4.48 & -4.33 & -3.95 \\
& -4.71 & -4.43 & -4.10 & -3.95 \\
\hline
\end{tabular}

posed to stem from destabilisation of the ${ }^{3} \mathrm{MC}$ states and hence the $\mathrm{d} \sigma^{*}$ orbitals in the ground state. Plots of the $\mathrm{d} \sigma^{*}$ orbitals of 1 to $\mathbf{4}$ are provided in Fig. 5. These appear as LUMO+13 \& LUMO+14 for 1 and LUMO+10 \& LUMO+11 for 4 and are destabilised by between 0.60 and $0.79 \mathrm{eV}$ relative to those of their ruthenium analogues. The ground state energy separation between the LUMO and the $\mathrm{d} \sigma^{*}$ orbitals decreases from $3.06 \mathrm{eV}$ for $\mathbf{1}$ to $2.07 \mathrm{eV}$ for $\mathbf{4}$ with the progressive destabilisation of the LUMO. This compares to a separation of $2.37 \mathrm{eV}$ for $\left[\mathrm{Ru}(\mathrm{bpy})_{3}\right]^{2+}$ and $1.27 \mathrm{eV}$ for $\left[\mathrm{Ru}(\mathrm{btz})_{3}\right]^{2+}$, which would therefore be expected to result in a significant increase in the ${ }^{3} \mathrm{MLCT}-{ }^{3} \mathrm{MC}$ state separation for the osmium series over their ruthenium analogues and account for the enhanced emission reported here.

Calculated absorption spectra from time-dependent DFT calculations are in good agreement with experimental spectra (see ESI†). Whilst the $\mathrm{S}_{1}$ states are all HOMO $\rightarrow$ LUMO ${ }^{1}$ MLCT 
in character these transitions are of low oscillator strength. The more intense transitions that give rise to the ${ }^{1} \mathrm{MLCT}$ bands involve transitions between the HOMO-1 or HOMO-2 to LUMO, LUMO+1 or LUMO+2 orbitals.

Since complexes 1 to 3 show photoluminescence at room temperature and display readily reversible Os(II)/Os(III) redox behaviour, they were tested as phosphorescent emitters in double layer LECs. Devices were prepared by spin-coating prepatterned ITO-glass substrates with an $80 \mathrm{~nm}$ thick PEDOT: PSS layer, in order to smooth the surface and increase the reproducibility of the devices. Subsequently, a layer of the phosphorescent complex was deposited from butanone (MEK) solutions, in the case of complexes $\mathbf{1}$ and 3, whereas acetonitrile was used to process complex 2 . In order to reduce the turn-on time of the device, the ionic liquid (IL) 1-butyl-3methylimidazolium hexafluorophosphate was added to the solutions in a molar ratio (complex : IL) of $4: 1$. Finally, an aluminium electrode was thermally evaporated onto the active layer. The characterisation of the LECs was carried out by applying a constant voltage $(3 \mathrm{~V})$ and monitoring the light output and the current over time. Under these conditions, a steady increase in the current and light output is typically observed as a consequence of the ion redistribution within the active layer. The ion drift reduces the barrier for charge injection and decreases the electrical resistance due to the formation of doped zones. ${ }^{59,60}$ The behaviour of complex 1 in LECs has been previously reported by Gao et al. ${ }^{53}$ hence this complex was used here as a reference. The device characteristics are depicted in Fig. 6 and the corresponding parameters summarised in Table 4.

All the LECs exhibit deep-red or near-infrared electroluminescence (EL) with emission maxima located between 695 and $730 \mathrm{~nm}$ (Fig. 6, panel d). The EL spectra show a rigidochromic blue-shift with respect to the corresponding fluid solution photoluminescence spectra (Fig. 3), in good agreement with
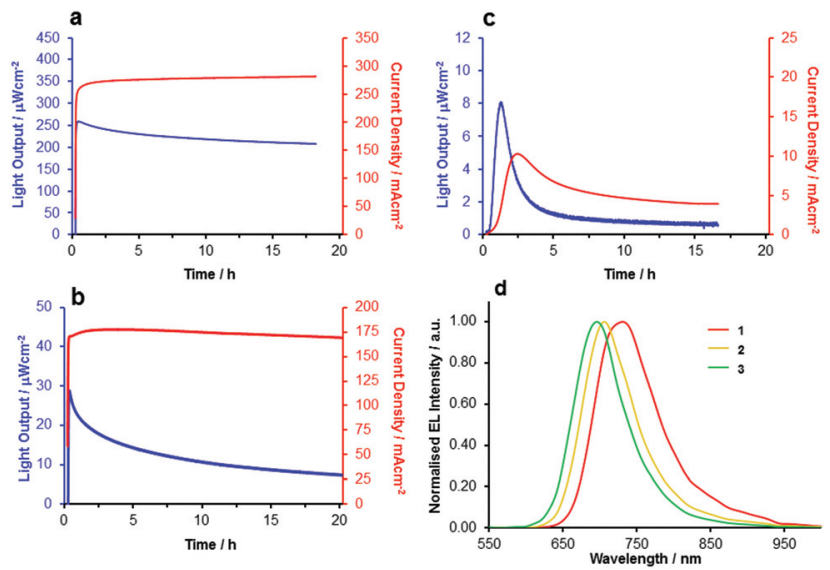

Fig. 6 Performance characteristics for LECs containing complexes 1-3: glass/ITO/PEDOT:PSS/complex:[Bmim][PF 6 ] $4: 1 / \mathrm{Al}$ under bias of $3 \mathrm{~V}$. Light output (blue lines) and current density (red lines) of the LECs containing 1 (a), 2 (b) and 3 (c). Graph (d) shows the electroluminescence spectra for the LECs prepared with 1-3.
Table 4 Device performance data for: ITO/PEDOT:PSS/Os-complex: [Bmim] $\left[\mathrm{PF}_{6}\right] / \mathrm{Al}$ under a bias of $3 \mathrm{~V}$. [Bmim] $\left[\mathrm{PF}_{6}\right]$ : 1-butyl-3-methylimidazolium hexafluorophosphate

\begin{tabular}{|c|c|c|c|c|c|}
\hline LEC complex:IL & Bias/V & $t_{\max } / \min$ & $L_{\max } / \mu \mathrm{W} \mathrm{cm}{ }^{-2}$ & $t_{1 / 2} / \mathrm{h}$ & $\mathrm{EQE}_{\max } / \%$ \\
\hline 1:[Bmim $]\left[\mathrm{PF}_{6}\right]$ & 3 & 14 & 259 & $>18$ & 0.06 \\
\hline $2:[\mathrm{Bmim}]\left[\mathrm{PF}_{6}\right]$ & 3 & 8 & 28 & 4.5 & 0.01 \\
\hline $3:[\mathrm{Bmim}]\left[\mathrm{PF}_{6}\right]$ & 3 & 63 & 8 & 1.9 & 0.30 \\
\hline
\end{tabular}

the emission observed at low temperature in rigid solution. As before, the increase in btz content upon moving from 1 to 3 is manifest in the shift of emission maxima to higher energy.

All LECs show the typical behaviour as described above, with different device responses being clearly observed dependent upon the identity of the active material. Differences in current $v s$. time profiles depend upon the ionic conductivity of the thin films and on the energy barrier for the injection of electrons or holes. ${ }^{61,62}$ In relation to 1 , the time to reach the maximum light output $\left(t_{\max }\right)$ was found to be shorter for LECs based on complex 2 and longer for the LEC containing 3 . Whilst these times do not reflect any appreciable trend across the series, the current density measured for each of the LECs varies substantially depending on the osmium complex, decreasing significantly upon the introduction of btz to the ligand set (1 to 2). In particular, LEC's containing $\mathbf{1}$ and $\mathbf{2}$ show a much higher current density and consequently more intense electroluminescence compared to devices based on 3 . Interestingly, this trend in current density across the series of complexes is not commensurate with changes in overall device efficiency, with the maximum external quantum efficiency (EQE) being achieved for the LECs containing complex 3 $(0.3 \%)$, found to be substantially higher in comparison to the reference complex $1(0.06 \%)$. It is noted that the performance characteristics measured for our devices containing $\mathbf{1}$ are in good agreement with those previously reported by Gao et al. for LECs fabricated with the same phosphor. ${ }^{53}$

Monitoring the photoluminescence output for the LECs over time reveals the device lifetime to be detrimentally affected by the sequential substitution of bpy ligands with btz. In spite of the high current density measured for the LEC, complex 1 shows a lifetime $\left(t_{1 / 2}\right)$ in excess of 18 hours, whereas complexes 2 and 3 were found to have shorter lifetimes of 4.5 and 1.9 hours, respectively. As further in-depth analysis of the different device performance of 3 was not carried out, we reason that the difference in current measured for 3 with respect to $\mathbf{1}$ and $\mathbf{2}$ is an indication of a lighter doping in the thin film of 3 , hence being less affected by exciton quenching. ${ }^{63}$

Despite the generally inferior device performance and brightness of LECs based on 2 and 3 the results are nonetheless encouraging for further phosphor development based on these architectures. During the fabrication of these devices problems were encountered for 2 due to crystallisation in the preparation of the active layer thin-films from MEK. These phosphors could therefore be modified through adding substi- 
tuents onto the bpy ligands and through use of different substituents on the btz ligands in attempts to improve the stability and photoluminescence emission of the active layer, and consequentially, device performance.

Since the complexes are also phosphorescent in solution with excitation at $600 \mathrm{~nm}$, the complexes may also be amenable to biological imaging applications in which auto-fluorescence can be negated. Here the CuAAC route to triazolebased ligand formation also lends itself to the inclusion of biologically relevant substituents within the ligand architecture for targeted cellular imaging. ${ }^{64}$ These and other possibilities are currently under investigation in our laboratory and results from these on-going studies will be published elsewhere in due course.

\section{Conclusions}

We have prepared and characterised heteroleptic osmium(II) bitriazolyl complexes $\left[\mathrm{Os}(\mathrm{bpy})_{2}(\mathrm{btz})\right]^{2+}(2)$ and $\left[\mathrm{Os}(\mathrm{bpy})(\mathrm{btz})_{2}\right]^{2+}$ (3) which display deep-red/near-IR emission in aerated fluid solution. The complexes are far more efficient phosphors than their previously reported ruthenium(II) analogues due to higher energy and less thermally accessible ${ }^{3} \mathrm{MC}$ states associated with the $5 \mathrm{~d}$ metal. The homoleptic complex $\left[\mathrm{Os}(\mathrm{btz})_{3}\right]^{2+}$ displays extremely weak room temperature emission but intense blue emission when cooled to $77 \mathrm{~K}$.

LECs have been prepared using complexes 1-3 that exhibit tuneable emission as a function of btz content within the ligand set. The electroluminescence of these devices ranges from deep-red to the near-infrared, being achievable at a low operating voltage. Whilst the introduction of triazole ligands was found to lead to an overall reduction in the current density and operational lifetime of the LECs, these results demonstrate the potential of Os(II) complexes as functional components within light-emitting devices where readily tuneable photoluminescence in the low energy region of the visible spectrum is desired.

\section{Experimental section}

$\left[\mathrm{Os}(\mathrm{bpy})_{3}\right]\left[\mathrm{PF}_{6}\right]_{2},{ }^{65}\left[\mathrm{Os}(\mathrm{bpy})_{2} \mathrm{Cl}_{2}\right],^{65}\left[\left\{\mathrm{Os}\left(\eta^{6}-\mathrm{C}_{6} \mathrm{H}_{6}\right) \mathrm{Cl}_{2}\right\}_{2}\right]^{66}$ and $\mathrm{btz}^{33,67}$ were prepared according to previously reported procedures. All reagents were purchased from Alfa Aesar, Acros Organics and Sigma-Aldrich and were used as received. Unless otherwise stated all synthetic manipulations were carried out under an atmosphere of $\mathrm{N}_{2}$ using standard Schlenck line techniques. Deaeration of solvents was performed through vigorous bubbling with $\mathrm{N}_{2}$ for a period of at least 15 minutes. NMR spectra were recorded on a Bruker Ascend $400 \mathrm{MHz}$ spectrometer, with all chemical shifts reported in ppm, calibrated relative to the residual solvent signal $\left(\mathrm{MeCN},{ }^{1} \mathrm{H}: \delta 1.94,{ }^{13} \mathrm{C}: \delta\right.$ $1.32,118.26)$. High resolution mass spectrometry was performed on an Agilent 6210 TOF instrument with a dual ESI source. Cyclic voltammograms were measured using an
Autolab PGSTAT100N potentiostat with NOVA electrochemical software. Analyte solutions were prepared using $\mathrm{N}_{2}$ saturated dry dichloromethane, freshly distilled from $\mathrm{CaH}_{2}$. All measurements were conducted at room temperature under a stream of dry $\mathrm{N}_{2}$ at potential scan rates ranging from 50 to $500 \mathrm{mV} \mathrm{s}^{-1}$. $\mathrm{NBu}_{4} \mathrm{PF}_{6}$ was used as a supporting electrolyte, being recrystallised from ethanol and oven dried prior to use, with a typical solution concentration of $0.2 \mathrm{~mol} \mathrm{dm}{ }^{-3}$. The working electrode was a platinum disc, with platinum wire utilised as the counter electrode. The reference electrode was $\mathrm{Ag} / \mathrm{AgCl}$, being chemically isolated from the analyte solution by an electrolyte containing bridge tube tipped with a porous frit. Ferrocene was employed as an internal reference, with all potentials quoted relative to the $\mathrm{Fc}^{+} / \mathrm{Fc}$ couple. UV-Visible electronic absorption spectra were recorded on an Agilent Cary-60 spectrophotometer, utilising quartz cuvettes of $1 \mathrm{~cm}$ pathlength. Emission spectra were recorded on a Fluoromax-4 spectrophotometer utilising quartz cuvettes of $1 \mathrm{~cm}$ pathlength. 'Degassed' solutions were prepared via three repeat 'freeze-pump-thaw' cycles. Quantum yields $\left(\Phi_{\mathrm{em}}\right)$ are quoted relative to $\left[\mathrm{Ru}(\mathrm{bpy})_{3}\right]\left[\mathrm{PF}_{6}\right]_{2}$ in aerated $\mathrm{MeCN}$, with all complexes being excited at a single wavelength with common optical density. Quantum yields are thus determined from the ratio of integrated area under the peaks. As emission bands for the Os complexes tail into the near infra-red region, outside the effective range of the spectrophotometer, an experimental uncertainty of $\pm 20 \%$ is assumed. Luminescence lifetimes were measured with an Edinburgh Instruments Mini$\tau$, equipped with a picosecond diode laser (404 nm, 56 ps) excitation source.

\section{Synthesis of $\left[\mathrm{Os}(\mathrm{bpy})_{2}(\mathrm{btz})\right]\left[\mathrm{PF}_{6}\right]_{2}(2)$}

[Os(bpy $\left.)_{2} \mathrm{Cl}_{2}\right]$ (125 mg, $\left.0.218 \mathrm{mmol}\right)$ and btz (69 mg, $0.218 \mathrm{mmol})$ were dissolved in ethylene glycol $(50 \mathrm{ml})$ and refluxed under $\mathrm{N}_{2}$ for 4.5 hours. The resulting dark green solution was cooled to room temperature, at which point $\mathrm{NH}_{4} \mathrm{PF}_{6}$ (119 $\mathrm{mg}, 0.733 \mathrm{mmol}$ ) was added and the solution stirred for a further 45 minutes. The resulting dark green precipitate was collected by filtration and washed with cold $\mathrm{H}_{2} \mathrm{O}$ followed by $\mathrm{Et}_{2} \mathrm{O}$. The solids were subsequently re-dissolved in MeCN and filtered through a celite plug, with the concentrated filtrate being passed through a silica column $\left(5 \% \mathrm{MeOH} / \mathrm{CH}_{2} \mathrm{Cl}_{2}\right.$ as eluent). Collection of the dark green coloured band and evaporation of the solvent afforded the product as a dark green solid. Yield = $130 \mathrm{mg}, 54 \% .{ }^{1} \mathrm{H}$ NMR $\left(\mathrm{CD}_{3} \mathrm{CN}, 400 \mathrm{MHz}\right): 5.45$ (d, $\left.J=15.0 \mathrm{~Hz}, 2 \mathrm{H}, \mathrm{CH}_{2}\right), 5.49$ (d, $J=15.0 \mathrm{~Hz}, 2 \mathrm{H}, \mathrm{CH}_{2}$ ), $7.05-7.10(\mathrm{~m}, 4 \mathrm{H}, b p y), 7.24(\mathrm{t}, J=6.6 \mathrm{~Hz}, 2 \mathrm{H}, P h), 7.30-7.39$ (m, 8H, Ph), 7.78-7.89 (m, 8H, bpy), 8.34 (s, 2H, Trz), 8.39-8.47 (m, 4H, bpy). ${ }^{13} \mathrm{C}$ NMR $\left(\mathrm{CD}_{3} \mathrm{CN}, 101 \mathrm{MHz}\right): 56.26,124.51$, 124.61, 124.91, 128.08, 128.79, 128.95, 129.91, 130.04, 134.85, $137.80,137.81,142.72$, 152.19, 152.76, 160.37, 161.03. HRMS (ES); $m / z$ calc. for $\left[\mathrm{OsC}_{38} \mathrm{H}_{32} \mathrm{~N}_{10}\right]^{2+}: 410.1208$, found: 410.1216 .

\section{Synthesis of $\left[\mathrm{Os}\left(\eta^{6}-\mathrm{C}_{6} \mathrm{H}_{6}\right)(\mathrm{bpy}) \mathrm{Cl}\right]\left[\mathrm{PF}_{6}\right]$}

$\left[\left\{\mathrm{Os}\left(\eta^{6}-\mathrm{C}_{6} \mathrm{H}_{6}\right) \mathrm{Cl}_{2}\right\}_{2}\right](260 \mathrm{mg}, 0.383 \mathrm{mmol})$ and 2,2'-bipyridine (119 $\mathrm{mg}, 0.762 \mathrm{mmol}$ ) were added to deaerated $\mathrm{MeOH}(20 \mathrm{ml})$ 
and stirred at $30{ }^{\circ} \mathrm{C}$ under $\mathrm{N}_{2}$ in the dark for 17 hours. The dark green solution was then passed through a short celite plug and the filtrate treated with $\mathrm{NH}_{4} \mathrm{PF}_{6}(363 \mathrm{mg}, 2.22 \mathrm{mmol}$, excess). The volume of the solvent was reduced by half to achieve complete precipitation of the bright yellow coloured product which was collected by filtration and washed with water followed by $\mathrm{Et}_{2} \mathrm{O}$. Yield $=335 \mathrm{mg}, 72 \%$. ${ }^{1} \mathrm{H}$ NMR $\left(\mathrm{CD}_{3} \mathrm{CN}, 400 \mathrm{MHz}\right): 6.14\left(\mathrm{~s}, 6 \mathrm{H}, \eta^{6}-C_{6} H_{6}\right), 7.64(\mathrm{dd}, J=6.4,6.6$ $\mathrm{Hz}, 2 \mathrm{H}, b p y), 8.17$ (dd $J=7.6,7.7 \mathrm{~Hz}, 2 \mathrm{H}, b p y), 8.40$ (d, $J=$ $8.1 \mathrm{~Hz}, 2 \mathrm{H}, b p y), 9.34(\mathrm{~d}, J=5.5 \mathrm{~Hz}, 2 \mathrm{H}, b p y) .{ }^{13} \mathrm{C}$ NMR ( $\left.\mathrm{CD}_{3} \mathrm{CN}, 101 \mathrm{MHz}\right)$ : 79.02, 124.80, 129.19, 141.07, 156.43, 156.53. HRMS (ES); $m / z$ calc. for $\left[\mathrm{OsC}_{16} \mathrm{H}_{14} \mathrm{~N}_{2} \mathrm{Cl}\right]^{+}: 461.0455$, found: 461.0443 .

\section{Synthesis of $\left[\mathrm{Os}\left(\eta^{6}-\mathrm{C}_{6} \mathrm{H}_{6}\right)(\mathrm{btz}) \mathrm{Cl}\right]\left[\mathrm{PF}_{6}\right]$}

$\left[\left\{\mathrm{Os}\left(\eta^{6}-\mathrm{C}_{6} \mathrm{H}_{6}\right) \mathrm{Cl}_{2}\right\}_{2}\right](210 \mathrm{mg}, 0.310 \mathrm{mmol})$ and btz were added to deaerated $\mathrm{MeOH}(30 \mathrm{ml})$ and stirred at $40{ }^{\circ} \mathrm{C}$ in the dark for 2.5 days. The dark green coloured solution was passed through a short celite plug and the filtrate treated with $\mathrm{NH}_{4} \mathrm{PF}_{6}$ (354 mg, $2.17 \mathrm{mmol}$, excess) before complete removal of the solvent. The residue was re-dissolved in $\mathrm{CH}_{2} \mathrm{Cl}_{2}$ and washed with a $50 \mathrm{ml}$ portion of $\mathrm{H}_{2} \mathrm{O}$. The organic phase was dried over $\mathrm{MgSO}_{4}$ and reduced in volume prior to purification by column chromatography $\left(\mathrm{SiO}_{2}, 1: 7 \mathrm{MeCN} / \mathrm{CH}_{2} \mathrm{Cl}_{2}\right)$. The product was obtained from the pale yellow coloured fraction, being precipitated from solution through the addition of excess hexane. Yield = $268 \mathrm{mg}, 56 \% .{ }^{1} \mathrm{H}$ NMR $\left(\mathrm{CD}_{3} \mathrm{CN}, 400 \mathrm{MHz}\right): 5.73$ (d, $J=$ $15 \mathrm{~Hz}, 2 \mathrm{H}, \mathrm{CH}_{2}$ ), 5.79 (d, $\left.J=15 \mathrm{~Hz}, 2 \mathrm{H}, \mathrm{CH}_{2}\right), 6.09,(\mathrm{~s}, 6 \mathrm{H}$, $\left.\eta^{6}-C_{6} H_{6}\right), 7.39-7.48(\mathrm{~m}, 10 \mathrm{H}, P h), 8.30$ (s, 2H, Trz). ${ }^{13} \mathrm{C}$ NMR $\left(\mathrm{CD}_{3} \mathrm{CN}, 101 \mathrm{MHz}\right): 56.71,77.78,123.86,129.47,130.19$, 130.21, 134.78, 140.73. HRMS (ES); $\mathrm{m} / \mathrm{z}$ calc. for $\left[\mathrm{OsC}_{24} \mathrm{H}_{22} \mathrm{~N}_{6} \mathrm{Cl}\right]^{+}$: 621.1204, found: 621.1180 .

\section{Synthesis of $\left[\mathrm{Os}(\mathrm{btz})_{2}(\mathrm{bpy})\right]\left[\mathrm{PF}_{6}\right]_{2}(3)$}

$\left[\mathrm{Os}\left(\eta^{6}-\mathrm{C}_{6} \mathrm{H}_{6}\right)(\mathrm{bpy}) \mathrm{Cl}\right]\left[\mathrm{PF}_{6}\right](173 \mathrm{mg}, 0.286 \mathrm{mmol})$, btz (184 mg, $0.582 \mathrm{mmol}$ ) and $\mathrm{NaPF}_{6}(169 \mathrm{mg}, 1.00 \mathrm{mmol}$, excess) were added to deaerated $3: 1(\mathrm{v} / \mathrm{v}) \mathrm{EtOH} / \mathrm{H}_{2} \mathrm{O}(16 \mathrm{ml})$. The reaction mixture was heated to $90{ }^{\circ} \mathrm{C}$ under $\mathrm{N}_{2}$ in the dark for 3 days. Upon cooling to room temperature, $\mathrm{NH}_{4} \mathrm{PF}_{6}(110 \mathrm{mg}$, $0.675 \mathrm{mmol}$, excess) was added to ensure complete precipitation of the product. The resulting solids were collected by filtration, being washed with $\mathrm{H}_{2} \mathrm{O}$ followed by $\mathrm{Et}_{2} \mathrm{O}$. Purification was achieved via column chromatography $\left(\mathrm{Al}_{2} \mathrm{O}_{3}, 4 \% \mathrm{MeOH} /\right.$ $\mathrm{CH}_{2} \mathrm{Cl}_{2}$ ), with the product eluting from the dark green coloured band. Evaporation of the solvent to a minimum volume and addition of hexane re-precipitated the title complex as a dark green powder. Yield $=132 \mathrm{mg}, 36 \% .{ }^{1} \mathrm{H}$ NMR (CD $\left.{ }_{3} \mathrm{CN}, 400 \mathrm{MHz}\right): 5.47\left(\mathrm{~s}, 4 \mathrm{H}, \mathrm{CH}_{2}\right), 5.53\left(\mathrm{~s}, 4 \mathrm{H}, \mathrm{CH}_{2}\right)$, 7.07-7.13 (m, 4H,Ph), $7.15(\mathrm{~d}, J=7.1 \mathrm{~Hz}, 4 \mathrm{H}, P h), 7.27(\mathrm{t}, J=$ $6.5 \mathrm{~Hz}, 2 \mathrm{H}, b p y), 7.30-7.41(\mathrm{~m}, 12 \mathrm{H}, P h), 7.83(\mathrm{t}, J=7.7 \mathrm{~Hz}, 2 \mathrm{H}$, bpy), 7.93 (d, J = 5.6 Hz, 2H, bpy), 8.30 (s, 2H,Trz), $8.33(\mathrm{~s}, 2 \mathrm{H}$, $\operatorname{Trz}$ ), 8.38 (d, $J=8.1 \mathrm{~Hz}, 2 \mathrm{H}, b p y) .{ }^{13} \mathrm{C} \mathrm{NMR}\left(\mathrm{CD}_{3} \mathrm{CN}, 101 \mathrm{MHz}\right)$ : 56.11, 56.32, 123.76, 124.09, 124.29, 127.85, 128.66, 129.04, 129.84, 129.93, 130.04, 130.06, 134.95, 135.21, 137.56, 142.99, 143.54, 153.19, 161.19. HRMS (ES); $\mathrm{m} / \mathrm{z}$ calc. for $\left[\mathrm{OsC}_{46} \mathrm{H}_{40} \mathrm{~N}_{14}\right]^{2+}$ : 490.1582 , found: 490.1589 .

\section{Synthesis of $\left[\mathrm{Os}(\mathrm{btz})_{3}\right]\left[\mathrm{PF}_{6}\right]_{2}(4)$}

$\left[\mathrm{Os}\left(\eta^{6}-\mathrm{C}_{6} \mathrm{H}_{6}\right)(\mathrm{btz}) \mathrm{Cl}\right]\left[\mathrm{PF}_{6}\right](223 \mathrm{mg}, 0.291 \mathrm{mmol})$, btz (184 mg, $0.581 \mathrm{mmol}$ ) and $\mathrm{NaPF}_{6}(263 \mathrm{mg}, 1.57 \mathrm{mmol}$, excess) were added to deaerated $3: 1(\mathrm{v} / \mathrm{v}) \mathrm{EtOH} / \mathrm{H}_{2} \mathrm{O}(20 \mathrm{ml})$. The reaction mixture was heated to $90{ }^{\circ} \mathrm{C}$ under $\mathrm{N}_{2}$ in the dark for 2 days. The resultant clear orange coloured solution was allowed to cool to room temperature, with $\mathrm{NH}_{4} \mathrm{PF}_{6}(190 \mathrm{mg}, 1.17 \mathrm{mmol}$, excess) then added to ensure complete precipitation of the product. The pale yellow solids were collected by filtration, washed with $\mathrm{H}_{2} \mathrm{O}$ followed by $\mathrm{Et}_{2} \mathrm{O}$ and dried in vacuo. Purification was achieved by column chromatography protected from light $\left(\mathrm{SiO}_{2}, 1: 9 \mathrm{MeCN} / \mathrm{CH}_{2} \mathrm{Cl}_{2}\right)$. The product was obtained from the pale yellow coloured band, being precipitated from solution by addition of hexane. Yield $=122 \mathrm{mg}$, 29\%. ${ }^{1} \mathrm{H}$ NMR ( $\left.\mathrm{CD}_{3} \mathrm{CN}, 400 \mathrm{MHz}\right): 5.50$ (s, 12H CH${ }_{2}$ ), 7.14 (dd, $J=1.7,7.5 \mathrm{~Hz}, 12 \mathrm{H}, P h), 7.29-7.38(\mathrm{~m}, 18 \mathrm{H}, P h), 8.33(\mathrm{~s}, 6 \mathrm{H}$, $\operatorname{Trz}) .{ }^{13} \mathrm{C}$ NMR ( $\left.\mathrm{CD}_{3} \mathrm{CN}, 101 \mathrm{MHz}\right): 56.14,123.52,128.76$, 129.85, 130.05, 135.23, 143.66. HRMS (ES); $\mathrm{m} / \mathrm{z}$ calc. for $\left[\mathrm{OsC}_{54} \mathrm{H}_{48} \mathrm{~N}_{18}\right]^{2+}$ : 570.1957, found: 570.1965.

\section{Computational details}

DFT calculations were carried out using the NWChem6.5 software package. ${ }^{68}$ Geometry optimisations were carried out using the B3LYP functional in the gas-phase. ${ }^{69}$ The StuttgartDresden relativistic small-core effective-core potential was used for osmium $^{70}$ with $6-311 G^{*}$ basis sets used for all other atoms. ${ }^{71}$ The ground state orbital energies were calculated in a single point calculation applying the $\mathrm{COSMO}^{72}$ solvation model for acetonitrile and plotted using the ECCE graphical user interface for NWChem.

\section{LEC preparation and testing}

Device preparation. LECs were prepared on top of a patterned indium tin oxide (ITO, $15 \Omega \mathrm{sq}^{-1}$ ) coated glass substrate) previously cleaned as follows: (a) sonication with soap, (b) deionised water, (c) isopropanol and (d) $\mathrm{UV}-\mathrm{O}_{3}$ lamp for $20 \mathrm{~min}$. The thickness of the films was determined with an Ambios XP-1 profilometer. Prior to the deposition of the emitting layer, $80 \mathrm{~nm}$ of poly(3,4-ethylenedioxythiophene):poly (styrene-sulfonate) (PEDOT:PSS) (CLEVIOS ${ }^{\mathrm{TM}} \mathrm{P}$ VP AI 4083, aqueous dispersion, $1.3-1.7 \%$ solid content, Heraeus) was coated in order to increase the reproducibility of the cells. The emitting layer $(100 \mathrm{~nm})$ was prepared by spin-coating of a solution consisting of the emitting compound with the addition of an ionic liquid 1-butyl-3-methylimidazolium hexafluorophosphate $[\mathrm{Bmim}]\left[\mathrm{PF}_{6}\right](>98.5 \%$, Sigma-Aldrich) in a 4 to 1 molar ratio. The devices were then transferred to an inert atmosphere glovebox $\left(<0.1\right.$ ppm $\mathrm{O}_{2}$ and $\left.\mathrm{H}_{2} \mathrm{O}, \mathrm{MBraun}\right)$, where a layer $(70 \mathrm{~nm})$ of aluminium (the top electrode) was thermally evaporated onto the devices using an Edwards Auto500 evaporator integrated in the inert atmosphere glovebox. The area of the device was $6.5 \mathrm{~mm}^{2}$. The devices were not encapsulated and were characterized inside the glovebox at room temperature.

Device characterisation. The device lifetime was measured by applying constant voltage and monitoring the current and 
the light output versus time using an integrating sphere (UDT Instruments, model 2525LE) coupled to a Radiometric Sensor (UDT Instruments, model 247) and an optometer (UDT Instruments, model S370). The electroluminescent (EL) spectra were measured using an Avantes AvaSpec2048 Fibre Optic Spectrometer during device lifetime measurement.

\section{Acknowledgements}

The authors thank the University of Huddersfield for supporting this work. As a member of the UK Materials Chemistry Consortium PIPE also thanks the EPSRC (EP/L000202) and the UK HPC national resource, Archer, as well as the Huddersfield High Performance Computing Research Group for computational recourses utilised in this work. We also thank Dr Anthony Haynes (The University of Sheffield) for a generous gift of the osmium salts. This work was also supported by the Spanish Ministry of Economy and Competitiveness (MINECO) (MAT2014-55200 and MDM-2015-0538) and the Generalitat Valenciana (Prometeo/2012/053).

\section{References}

1 V. Balzani, P. Ceroni and A. Juris, Photochemistry and Photophysics: Concepts, Research, Applications, Wiley-VCH, 2014.

2 D. Kumaresan, K. Shankar, S. Vaidya and R. H. Schmehl, Top. Curr. Chem., 2007, 281, 101-142.

3 A. Hagfeldt, G. Boschloo, L. Sun, L. Kloo and H. Pettersson, Chem. Rev., 2010, 110, 6595-6663.

4 W. T. Eckenhoff and R. Eisenberg, Dalton Trans., 2012, 41, 13004-13021.

5 M. D. Kärkäs, O. Verho, E. V. Johnston and B. Åkermark, Chem. Rev., 2014, 114, 11863-12001.

6 R. C. Evans, P. Douglas and C. J. Winscom, Coord. Chem. Rev., 2006, 250, 2093-2126.

7 R. D. Costa, E. Ortí and H. J. Bolink, Pure Appl. Chem., 2011, 83, 2115-2128.

8 J. A. G. Williams, Chem. Soc. Rev., 2009, 38, 1783-1801.

9 E. M. Kober, J. V. Caspar, R. S. Lumpkin and T. J. Meyer, J. Phys. Chem., 1986, 90, 3722-3734.

10 J. V. Caspar, E. M. Kober, B. P. Sullivan and T. J. Meyer, J. Am. Chem. Soc., 1982, 104, 630-632.

11 J. V. Caspar, T. D. Westmoreland, G. H. Allen, P. G. Bradley, T. J. Meyer and W. H. Woodruff, J. Am. Chem. Soc., 1984, 106, 3492-3500.

12 H. Yersin, P. Huber and D. Braun, J. Phys. Chem., 1990, 94, 3560-3564.

13 A. Juris, L. Prodi, A. Harriman, R. Ziessel, M. Hissler, A. Elghayoury, F. Wu, E. C. Riesgo and R. P. Thummel, Inorg. Chem., 2000, 39, 3590-3598.

14 J.-P. Sauvage, J.-P. Collin, J.-C. Chambron, S. Guillerez, C. Coudret, V. Balzani, F. Barigelletti, L. De Cola and L. Flamigni, Chem. Rev., 1994, 94, 993-1019.
15 C. Bhaumik, D. Saha, S. Das and S. Baitalik, Inorg. Chem., 2011, 50, 12586-12600.

16 E. C. Constable, C. E. Housecroft, A. C. Thompson, P. Passaniti, S. Silvi, M. Maestri and A. Credi, Inorg. Chim. Acta, 2007, 360, 1102-1110.

17 R. E. Holmlin, J. A. Yao and J. K. Barton, Inorg. Chem., 1999, 38, 174-189.

18 R. E. Holmlin, E. D. A. Stemp and J. K. Barton, J. Am. Chem. Soc., 1996, 118, 5236-5244.

19 L. D. Cola and P. Belser, Coord. Chem. Rev., 1998, 177, 301346.

20 S. Serroni, S. Campagna, F. Puntoriero, C. Di Pietro, N. D. McClenaghan and F. Loiseau, Chem. Soc. Rev., 2001, 30, 367-375.

21 F. Puntoriero, F. Nastasi, M. Cavazzini, S. Quici and S. Campagna, Coord. Chem. Rev., 2007, 251, 536-545.

22 A. Ito, T. E. Knight, D. J. Stewart, M. K. Brennaman and T. J. Meyer, J. Phys. Chem. A, 2014, 118, 10326-10332.

23 L.-H. Chung, S.-C. Chan, W.-C. Lee and C.-Y. Wong, Inorg. Chem., 2012, 51, 8693-8703.

24 S. Altobello, R. Argazzi, S. Caramori, C. Contado, S. D. Fré, P. Rubino, C. Choné, G. Larramona and C. A. Bignozzi, J. Am. Chem. Soc., 2005, 127, 15342-15343.

25 S. Verma, P. Kar, A. Das, D. K. Palit and H. N. Ghosh, J. Phys. Chem. C, 2008, 112, 2918-2926.

26 T. Lazarides, N. M. Tart, D. Sykes, S. Faulkner, A. Barbieri and M. D. Ward, Dalton Trans., 2009, 3971-3979.

27 J. D. Crowley and D. A. McMorran, Top. Heterocycl. Chem., 2012, 28, 31 .

28 M. Obata, A. Kitamura, A. Mori, C. Kameyama, J. A. Czaplewska, R. Tanaka, I. Kinoshita, T. Kusumoto, H. Hashimoto, M. Harada, Y. Mikata, T. Funabiki and S. Yano, Dalton Trans., 2008, 3292-3300.

29 Y. Li, J. C. Huffman and A. H. Flood, Chem. Commun., 2007, 2692-2694.

30 H. C. Bertrand, S. Clède, R. Guillot, F. Lambert and C. Policar, Inorg. Chem., 2014, 53, 6204-6223.

31 S. Ladouceur, D. Fortin and E. Zysman-Colman, Inorg. Chem., 2011, 50, 11514-11526.

32 B. Beyer, C. Ulbricht, D. Escudero, C. Friebe, A. Winter, L. González and U. S. Schubert, Organometallics, 2009, 28, 5478-5488.

33 L. Donato, P. Abel and E. Zysman-Colman, Dalton Trans., 2013, 42, 8402-8412.

34 K. N. Swanick, S. Ladouceur, E. Zysman-Colman and Z. Ding, Chem. Commun., 2012, 48, 3179-3181.

35 J. M. Fernández-Hernández, J. I. Beltrán, V. Lemaur, M.-D. Gálvez-López, C.-H. Chien, F. Polo, E. Orselli, R. Fröhlich, J. Cornil and L. De Cola, Inorg. Chem., 2013, 52, 1812-1824.

36 J. M. Fernández-Hernández, L. De Cola, H. J. Bolink, M. Clemente-León, E. Coronado, A. Forment-Aliaga, A. LópezMuñoz and D. Repetto, Langmuir, 2014, 30, 14021-14029.

37 J. M. Fernández-Hernández, C.-H. Yang, J. I. Beltrán, V. Lemaur, F. Polo, R. Fröhlich, J. Cornil and L. De Cola, J. Am. Chem. Soc., 2011, 133, 10543-10558. 
38 J. M. Fernández-Hernández, S. Ladouceur, Y. Shen, A. Iordache, X. Wang, L. Donato, S. Gallagher-Duval, M. de Anda Villa, J. D. Slinker, L. De Cola and E. ZysmanColman, J. Mater. Chem. C, 2013, 1, 7440-7452.

39 C. E. Welby, L. Gilmartin, R. R. Marriott, A. Zahid, C. R. Rice, E. A. Gibson and P. I. P. Elliott, Dalton Trans., 2013, 42, 13527-13536.

40 C. E. Welby, S. Grkinic, A. Zahid, B. S. Uppal, E. A. Gibson, C. R. Rice and P. I. P. Elliott, Dalton Trans., 2012, 41, 76377646.

41 C. E. Welby, G. K. Armitage, H. Bartley, A. Wilkinson, A. Sinopoli, B. S. Uppal, C. R. Rice and P. I. P. Elliott, Chem. - Eur. J., 2014, 20, 8467-8476.

42 C. E. Welby, G. K. Armitage, H. Bartley, A. Sinopoli, B. S. Uppal and P. I. P. Elliott, Photochem. Photobiol. Sci., 2014, 13, 735-738.

43 C. E. Welby, C. R. Rice and P. I. P. Elliott, Angew. Chem., Int. Ed., 2013, 52, 10826-10829.

44 J. T. Fletcher, B. J. Bumgarner, N. D. Engels and D. A. Skoglund, Organometallics, 2008, 27, 5430-5433.

45 U. Monkowius, S. Ritter, B. König, M. Zabel and H. Yersin, Eur. J. Inorg. Chem., 2007, 4597-4606.

46 A. M. Breul, I. R. de Moraes, R. Menzel, M. Pfeffer, A. Winter, M. D. Hager, S. Rau, B. Dietzek, R. Beckert and U. S. Schubert, Polym. Chem., 2014, 5, 2715-2724.

47 Q. Pei, G. Yu, C. Zhang, Y. Yang and A. J. Heeger, Science, 1995, 269, 1086-1088.

48 H.-C. Su, C.-C. Wu, F.-C. Fang and K.-T. Wong, Appl. Phys. Lett., 2006, 89, 261118.

49 H.-C. Su, H.-F. Chen, Y.-C. Shen, C.-T. Liao and K.-T. Wong, J. Mater. Chem., 2011, 21, 9653-9660.

50 D. Tordera, A. Pertegás, N. M. Shavaleev, R. Scopelliti, E. Ortí, H. J. Bolink, E. Baranoff, M. Grätzel and M. K. Nazeeruddin, J. Mater. Chem., 2012, 22, 19264-19268.

51 T. Hu, L. He, L. Duan and Y. Qiu, J. Mater. Chem., 2012, 22, 4206-4215.

52 Y. Shen, D. D. Kuddes, C. A. Naquin, T. W. Hesterberg, C. Kusmierz, B. J. Holliday and J. D. Slinker, Appl. Phys. Lett., 2013, 102, 203305.

53 F. G. Gao and A. J. Bard, Chem. Mater., 2002, 14, 3465-3470.

54 A. R. Hosseini, C. Y. Koh, J. D. Slinker, S. Flores-Torres, H. D. Abruña and G. G. Malliaras, Chem. Mater., 2005, 17, 6114-6116.
55 S. Bernhard, X. Gao, G. G. Malliaras and H. D. Abruña, Adv. Mater., 2002, 14, 433-436.

56 P.-T. Chou and Y. Chi, Eur. J. Inorg. Chem., 2006, 33193332.

57 E. M. Kober and T. J. Meyer, Inorg. Chem., 1982, 21, 39673977.

58 K. Suzuki, A. Kobayashi, S. Kaneko, K. Takehira, T. Yoshihara, H. Ishida, Y. Shiina, S. Oishi and S. Tobita, Phys. Chem. Chem. Phys., 2009, 11, 9850-9860.

59 S. van Reenen, P. Matyba, A. Dzwilewski, R. A. J. Janssen, L. Edman and M. Kemerink, J. Am. Chem. Soc., 2010, 132, 13776-13781.

60 M. Lenes, G. Garcia-Belmonte, D. Tordera, A. Pertegás, J. Bisquert and H. J. Bolink, Adv. Funct. Mater., 2011, 21, 1581-1586.

61 C. Roldán-Carmona, T. Akatsuka, M. Sessolo, S. E. Watkins and H. J. Bolink, ACS Appl. Mater. Interfaces, 2014, 6, 19520-19524.

62 J. H. Shin, P. Matyba, N. D. Robinson and L. Edman, Electrochim. Acta, 2007, 52, 6456-6462.

63 H.-C. Su and J.-H. Hsu, Dalton Trans., 2015, 44, 8330-8345.

64 N. Zabarska, A. Stumper and S. Rau, Dalton Trans., 2016, 45, 2338-2351.

65 T. W. Hamann, F. Gstrein, B. S. Brunschwig and N. S. Lewis, J. Am. Chem. Soc., 2005, 127, 7815-7824.

66 A. F. A. Peacock, A. Habtemariam, R. Fernández, V. Walland, F. P. A. Fabbiani, S. Parsons, R. E. Aird, D. I. Jodrell and P. J. Sadler, J. Am. Chem. Soc., 2006, 128, 1739-1748.

67 A. Mattiuzzi, I. Jabin, C. Moucheron and A. K.-D. Mesmaeker, Dalton Trans., 2011, 40, 7395-7402.

68 M. Valiev, E. J. Bylaska, N. Govind, K. Kowalski, T. P. Straatsma, H. J. J. van Dam, D. Wang, J. Nieplocha, E. Apra, T. L. Windus and W. A. de Jong, Comput. Phys. Commun., 2010, 181, 1477-1489.

69 P. J. Stephens, F. J. Devlin, C. F. Chabalowski and M. J. Frisch, J. Phys. Chem., 1994, 98, 11623-11627.

70 D. Andrae, U. Häussermann, M. Dolg, H. Stoll and H. Preuss, Theor. Chim. Acta, 1990, 77, 123-141.

71 R. Krishnan, J. S. Binkley, R. Seeger and J. A. Pople, J. Chem. Phys., 1980, 72, 650-654.

72 A. Klamt and G. Schüürmann, J. Chem. Soc., Perkin Trans. 2, 1993, 799-805. 